\title{
Modeling and experimental validation of a unitized regenerative fuel cell in electrolysis mode of operation
}

\author{
Amit C. Bhosale, Swapnil R. Mane, Debanand Singdeo, Prakash C. Ghosh* \\ Department of Energy Science and Engineering, Indian Institute of Technology Bombay, \\ Mumbai, India
}

\begin{abstract}
Unitized regenerative fuel cell (URFC) is considered to be the compact solution to generate and utilize hydrogen. It possesses combined capabilities of operating in fuel cell and electrolyser modes. In the present study, the performance of a URFC in electrolyser mode is modelled and also experimentally validated. The performances are being modelled using a combination of structural and CFD analysis tool. The effect of the operating gas pressure arising from the variation in the contact pressure between GDL and BPP on the performances are studied. The clamping pressure, as well as the operating pressure of the electrolyser, are seen to have a high impact on the contact resistance and thereby the performance as well. It is observed that the simulated polarization behavior is in good agreement with the experimental results. To restrict the area specific resistance below $150 \mathrm{~m} \Omega \mathrm{cm}^{2}$ the operating pressure should be maintained below 5.9 bar at clamping pressure of $1.5 \mathrm{MPa}$.
\end{abstract}

Keywords: Unitized regenerative fuel cell, Electrolyser, Contact resistance, Operating pressure, Clamping pressure

*Corresponding author

E-mail: pcghosh@iitb.ac.in, chhamugram@gmail.com

Ph.: +91-22-2576-7896, Fax : +91-22-2576-4890 


\section{Highlights}

- Dependence of ICR on clamping pressure is explored.

- Maximum operating pressure as a function of clamping pressure is investigated.

- Impact of ICR on the URFC performance in electrolysis is evaluated. 


\section{Introduction}

In the light of global warming and negative consequences of the dependence on the conventional fossil fuel resources, hydrogen fuel based economy is believed to be a promising alternative solution [1]. Although hydrogen fuel offers several advantages compared to the fossil fuel and also abandoned in nature, it must be derived from other resources and requires energy input. Waste heat from nuclear power plant [2-4] could be considered as an intermediate solution for the energy sources and renewable energy viz., solar energy [5-7] and wind energy [8,9] can be considered as a long-term sustainable solution for the input for deriving hydrogen fuel. Different roles of hydrogen in the renewable system have been demonstrated in industrial scale [10-12] as well as small scale [13]. In renewable system, hydrogen is derived from water using electrolyser and it is utilized in fuel cells to meet electrical demand.

Fuel cells are electrochemical energy conversion devices that possess several operational advantages include quick start-up, high efficiency, low operating temperature, noise free operation and lower emissions than fossil fuel-based devices [14-17]. Alike fuel cells, electrolysers are also electrochemical devices capable of splitting water into hydrogen and oxygen electrochemically. In most of the renewable system where hydrogen is explored as a medium for energy storage to cater the mismatches in the demand and supply of power, combination of electrolysers and fuels cells are explored. Unitized regenerative fuel cells (URFCs) are able to work in both fuel cell mode and an electrolyser mode $[18,19]$. This makes them be an alternative candidate to club with renewable energy sources for hydrogen generation and utilization, particularly for the standalone system [20-22]. However, URFCs are still undergoing intense research and development to address issues related to the complexity associated with the scale ups and durability. The durability is affected due to the redox reaction of oxygen at oxygen electrode resulting in faster decay in performance compared to that of fuel 
cells and electrolysers individually [23,24]. A URFC is composed of the membrane electrode assembly (MEA) with bipolar plate (BPP) on each side which is further enclosed within a pair of end plates. The entire assembly is brought into an electrical contact using clamping pressure applied using bolts. If clamping pressure is non-uniform and non-optimized, the performance of the cell will be affected. The decrease is primarily due to interfacial ohmic loss, which may be significant if non-optimal clamping pressure is applied. In particular, the loss is very sensitive to the electrical contact at the interface of the BPP and gas diffusion layer (GDL) $[25,26]$.

As the issue of the contact resistance is also of relevance to the fuel cells, extensive work has been carried out to study its behavior [27-29] in connection with the clamping pressure [30,31]. Researchers have suggested changing the surface topology of BPP viz., surface treatment [32] and conductive coatings [33-35] as the possible solutions to reduce Interfacial Contact Resistance (ICR). Oyarceet et al. [36] observed a decrease in contact resistance with respect to the temperature and relative humidity $(\mathrm{RH})$ of gasses. However, higher current density resulted in the production of excessive water on the cathode side which increased the contact resistance, especially for the uncoated SS316 sample. Bates et al. [37] analytically observed the contact pressure distribution between GDL and BPP for the PEMFC stack. It was observed that the pressure at the interface was negligible regardless of the clamping pressure. Dey et al. [38] experimentally validated their theoretical model which dealt with the ICR between the electrode and interconnect for the solid oxide fuel cell.

Lee et al. [39] studied the influences of the GDL and clamping torque on the performances of the fuel cells at a fixed stoichiometric flow rate of gases. It was observed that incompressible GDL showed the highest performance at low clamping torque. However, increase in clamping torque 
enhanced the performance of cell with softer GDL which was attributed to respective changes in porosity and contact resistance.

Bograchev et al. [40] proposed a 2D elastoplastic model (elastic for metallic components and plastic for membrane) for fuel cell against mechanical stresses. The model proved plastic deformation of membrane below gasket and bipolar plate at $15.8 \mathrm{~N}-\mathrm{m}$ which was confirmed experimentally.

Although structurally fuel cells and electrolysers are almost similar, different materials are used for the components in the electrolyser as their operating environment is different. Based on such concept, Selamet et al. [41] examined the effect of the bolt torque on the contact resistance in the PEM electrolyser using different gaskets. They observed the pressure distribution with pressure sensitive films between the gaskets and found that contact resistance and thereby performance did not decrease drastically for PTFE gasket under different clamping pressure. Siracusano et al. [42] experimented with the effect of thickness variation of GDL/current collector on ICR for PEM electrolyser stack and found that thicker titanium grid had lower contact resistance possibly due to better contact with BPP. Moreover, no further enhancement in the performance was observed between 15 to $25 \mathrm{~kg} \mathrm{~cm}^{-2}$.

However, the effect of the operating gas pressure on contact pressure and thereby ICR has not been studied in the case of electrolysers. As gas pressure rises, it is suspected that it would try to counter the contact pressure that maintains electrical contact between BPP and GDL. This will definitely cause the contact pressure between them to drop during operation which will end up in increasing the ICR. Authors, therefore, investigate such effect at different clamping pressure for URFC in the electrolysis mode. It is important to observe the contact pressure developed at the interface of GDL and BPP which would relate to corresponding contact resistance between them. 
Experimental validation has been done to support the modeling. The analysis done herewith shall be useful in predicting the approximate pressure of gas that the cell could withstand against acceptable contact resistance for a given clamping pressure.

\section{Methodology:}

Interfacial contact resistance mainly, between BPP and GDL inside a unitized regenerative fuel cell, contributes significantly, under a non-optimal clamping condition. It is also affected by the operating pressure. Hence, it is important to investigate the contact resistance behavior of the interfacial plates under different clamping pressure and gas operating pressure. The experimental details for measuring the interfacial contact resistance under different clamping pressure is discussed in the following sections.

\subsection{Experimental setup}

\subsubsection{Measurement of contact pressure distribution}

Spatial distribution of interfacial pressure between different components in the URFC plays an important role in the overall performances. In general, the spatial distribution of the contact pressure between the electrode and bipolar plate is observed in a large area cell which dictates the local internal resistance of a cell. In the present study, pressure sensitive films were explored to study the contact pressure distribution at the interface. Pressure sensitive films suitable for use in the range from 0.2 till $0.5 \mathrm{MPa}$ were used in present study.

\subsubsection{Measurement of ICR}

In order to convert the interfacial resistance distribution from the pressure distribution, obtained from the pressure sensitive films, the correlation between the contact pressure and contact resistance is important. In the present study, the contact resistance between a sample of SS 316 
coated with titanium nitride $(\mathrm{TiN})$ and carbon paper, were cut into appropriate size $(1 \mathrm{~cm} \times 1 \mathrm{~cm})$. The experimental in-house device used for the measurement of contact resistances is shown in Fig. 1. The threaded screw was used to convert rotary motion into axial motion. The contact pressure with respect to spindle turns was calibrated using pressure sensitive films. Carbon paper was fixed on the bottom of the top plate whereas coated SS sample was fixed on top of bottom plate ensuring that the samples could face each other all the time. The connections were drawn from the samples and connected to the DAQ that was monitored through a computer.

\subsubsection{Membrane Electrode Assembly}

In order to characterize and validate the simulation results, MEA was prepared by initially treating the membrane (NR-212) with $\mathrm{HNO}_{3}, \mathrm{H}_{2} \mathrm{O}_{2}$ and $\mathrm{H}_{2} \mathrm{SO}_{4}$ [43] respectively for one hour each to remove any organic and inorganic impurities and sulfonate at the end. GDL was prepared by coating an ink of Vulcan XC-72 (Loading $1.5 \mathrm{mg} \mathrm{cm}^{-2}$ ) mixed with PTFE (15 wt\%) in iso propyl alcohol (IPA) [44]. The coated paper was later sintered at $350^{\circ} \mathrm{C}$ for $30 \mathrm{~min}$ to help PTFE distribute uniformly over the paper. The catalyst ink with $0.1 \mathrm{mg} \mathrm{cm}^{-2}$ loading of $40 \% \mathrm{Pt} / \mathrm{C}$ with $7 \mathrm{wt} \%$ of nafion solution was then coated on GDL with a soft brush to make hydrogen electrode. However, $40 \% \mathrm{Pt} / \mathrm{C}$ and $\mathrm{IrO}_{2}$ together were mixed in IPA along with 30 wt\% of N.S. (total loading $0.5 \mathrm{mg} \mathrm{cm}^{-2}$ ) to coat the ink for oxygen electrode. The treated membrane was then sandwiched between the electrodes in a hot press with $65 \mathrm{~kg} \mathrm{~cm}^{-2}$ at $137^{0} \mathrm{C}$ for 2.5 min to fabricate the MEA [45].

\subsubsection{URFC assembly}

The cell assembly was prepared by holding MEA of an active area of $22.5 \mathrm{~cm}^{2}$, between a PTFE gaskets and a TiN coated BPP with serpentine flow field configuration followed by a silicon rubber sheet and an end plate on both sides. The studs were welded perpendicular to one of the 
end plates to reduce stacking time and act as guiding pins for the components. The different components used in the URFC assembly is shown in Fig. 2.

\subsection{Modeling of electrolysis performance}

Electrolysis performance has been characterized using a 3D, computational fluid dynamics (CFD) model. The effect of ICR at the interface of GDL and BPP has been included in the model. The simulated data has been validated with experimental polarization data and governing parameters have been found out.

\subsubsection{Assumptions}

It is assumed that the flow of gases is to be steady, laminar and single phase throughout the domain. In the case of water electrolysis, since hydrogen generation is found to be simpler than water oxidation, cathode contribution to overpotential is negligible compared to the anode. The resistivity of the electrolyte is assumed to be constant as the cell is simulated over low temperature $(<340 \mathrm{~K})$ and pressure $(0-8$ bar $)$ ranges. Porosity in the electrode, as well as GDL, is assumed to be uniform and the permeability to be isotropic. The transport of charge was assumed to be normal to the electrode and membrane area. External walls of the domain were kept at room temperature.

\subsubsection{Governing equations:}

Water can be dissociated into respective gases by supplying the electrical energy $(\Delta G)$ and the thermal energy $(T \Delta S)$ i.e., the enthalpy $(\Delta H)$ of water at a given instant (eq 1 and 2).

$2 \mathrm{H}_{2} \mathrm{O}+\Delta G+\mathrm{T} \Delta \mathrm{S} \rightarrow 2 \mathrm{H}_{2}+\mathrm{O}_{2}$

$\Delta H=\Delta G+T \Delta S$ 
The reactions at oxygen and hydrogen electrodes respectively could be summarized in following way:

$2 \mathrm{H}_{2} \mathrm{O} \rightarrow \mathrm{O}_{2}+4 \mathrm{H}^{+}+4 e^{-}$

$4 H^{+}+4 e^{-} \rightarrow 2 H_{2}$

The reversible potential [44] at a temperature $\mathrm{T}$ (in kelvin) and $1 \mathrm{~atm}$ pressure could be found out using Eq. 5.

$E_{\text {rev }}^{T}=E_{\text {rev }}^{0}-1 / n F\left\{(T-298.15) \times\left(\Delta C_{p}-\Delta S^{0}\right)-T \times \Delta C_{p} \times \ln \left\lfloor\frac{T}{298.15}\right\rfloor\right\}$

However, Nernst potential [44] gives open circuit voltage considering the effect of operating pressure (Eq. 6).

$E^{N}=E^{P, T}=E_{\text {rev }}^{T}-(R T / n F) \times \ln \left\{\frac{P_{\mathrm{H}_{2}} \times\left(P_{\mathrm{O}_{2}}\right)^{1 / 2}}{P_{\mathrm{H}_{2} \mathrm{O}}}\right\}$

Volumetric current densities [46] at anode and cathode can be respectively calculated using Butler-Volmer equation as

$J_{a n}=\zeta_{a n} j_{a n}^{r e f}\left\{\frac{[C]}{[C]_{\text {ref }}}\right\}^{y_{a n}}\left\{e^{-\alpha F \eta_{a n} / R T}-e^{\alpha F \eta_{a n} / R T}\right\}$
$J_{\text {cat }}=\zeta_{\text {cat }} j_{\text {cat }}^{r e f}\left\{\frac{[C]}{[C]_{\text {ref }}}\right\}^{y_{c a t}}\left\{e^{\left.-\alpha F \eta_{c a t} / R T-e^{+\alpha F \eta_{c a t} / R T}\right\}}\right.$

And the source terms and sink terms [47] in case of electrolysis could be written as following;

$S_{H_{2}}=\left\{M_{w, H_{2}} / 2 F\right\} J_{c a t}>0$

$S_{O_{2}}=\left\{M_{w, O_{2}} / 4 F\right\} J_{a n}>0$

$S_{\mathrm{H}_{2} \mathrm{O}}=\left\{M_{w, H_{2} \mathrm{O}} / 2 \mathrm{~F}\right\} J_{\text {an }}<0$ 
Total resistance [28] that arises from ionically and electronically conducting mediums are given by

$R_{t o t}=R_{a c t}+R_{\text {ohmic }}+R_{e_{-} t o t}$

$R_{e_{-} \text {tot }}=R_{G D L}+R_{B P P}+\left(R_{I C R} / A_{\text {electrode }}\right)$

13

The local current density can now be deduced from operating potential with the help of the following equation:

$J_{\text {avg }}=\frac{E}{R_{\text {tot }} \times A_{\text {electrode }}}$

\subsubsection{Computational procedure}

The geometry was created in Ansys 14.5 and hexahedral type meshing was adopted in all domains. Mesh optimization was carried out after importing the geometry in solver (Ansys Fluent 16). The governing equations were discretized using SIMPLE algorithm and boundary conditions were set on respective surfaces followed by solution initialization. The solution was under-relaxed against the stability of the species and energy conservation equations. This was achieved by setting the value of 0.8 for the species and 0.8 for the energy term in the beginning. In due course of the solution, these values were increased depending upon the nature of the solution. The solution was deemed to be converged when the residuals of all the conserved quantitative dropped below $10^{-6}$. 


\subsubsection{Boundary conditions:}

The average molar flow rate for hydrogen produced during water electrolysis could be calculated using following equation.

$$
\cdot \dot{\mathrm{m}}_{\mathrm{H}_{2}}=\frac{\text { Javg } \cdot A_{\text {electrode }}}{2 \mathrm{~F}}
$$

Where, $\mathrm{J}_{\text {avg }}$ is the average current density applied to the cell at a particular voltage; $\mathrm{A}_{\text {electrode }}$ is the active area of the electrode.

The temperature of water at the inlet was set to be $333 \mathrm{~K}$ for all simulations and pressure outlet type boundary condition (atmospheric pressure) was enforced at the outlets. Area specific contact resistance and operating pressure i.e. gas pressure were varied with respect to operating conditions. Electric potential was specified at the anode side whereas the same was assumed to be zero at the cathode side.

\section{Results and discussion:}

\subsection{Interfacial contact resistance}

Fig. 3 shows the variation of contact resistance with contact pressure (CP) between carbon paper and TiN based bipolar plate. It could be seen that the area-specific ICR decreased exponentially with the increase in the contact pressure as reported by L. Wang et al. [48] thereby emphasizing the fact that the contact pressure plays a dominant role in the internal resistance of the URFCs. The value of the area specific ICR decreased with the increase in the contact pressure and dropped to a value of $0.059 \Omega \mathrm{cm}^{2}$ at $0.46 \mathrm{MPa}$. This decrease is attributed to more area of carbon paper coming in contact with BPP as and when the pressure was increased. The experimental results have been fitted using following empirical equation which was further incorporated in CFD model. 
$R_{I C R}=-1.02012+(2.92053 / C P)+(0.09624 \times C P)$

Although there has been slight deviation of the fit from experimental curve predominantly in the initial range of contact pressure $(\leq 2.6 \mathrm{MPa})$, it was acceptable as higher contact pressures have been considered in most of the simulations. The slight decrease in bulk resistance of carbon paper was observed as it gradually got compressed with an increase in contact pressure; mainly because of bringing more fibers in contact with each other.

\subsection{Distribution and validation of contact pressure}

Clamping pressure of $1 \mathrm{MPa}$ has been taken as a case for comparative study and detailed analysis of spatial stress variation over electrode has been carried out. The simulated distribution of the contact pressure on the electrode surface is shown in Fig. 4a and the pressure distributions of similar assembly obtained from the pressure film measurement are presented in Fig. 4b. Higher stresses on the edges could be observed in both the studies due to excessive pressing on the electrodes by the BPP mainly due to the positioning of bolts along the edges of the cell. Fig. 4c shows the statistical distribution of the contact pressure distribution obtained from the simulated results. From the figure, it is clear that majority of the areas lies between $0.8 \mathrm{MPa}$ to $1 \mathrm{MPa}$. The average contact pressure obtained from the simulation were experimentally validated for different clamping pressures. Approximately, a linear relationship was observed between the two in the case of both experimental as well as simulation results (Fig. 4d) and both seem to be in good agreement. The properties of the materials those were used in the structural simulation are

summarized in Table 1. The properties for the gaskets were obtained experimentally using nanoindentation equipment. 


\subsection{Gas pressure vs contact pressure at different clamping pressure}

Structural simulation for the cell was carried out for different gas pressures at various clamping pressures. The variation in the average contact pressure at the interface of the BPP and GDL is shown in Fig. 5. It was observed that the average contact pressure decreases linearly with increase in the gas pressure. The effect was observed as the gas pressure tried to separate out the contact between BPP and MEA and thereby GDL.

\subsection{ICR vs gas pressure at different clamping pressure}

The variation of operating gas pressure was further extended to see its impact on ICR at different clamping pressure as given in Fig. 6 . In the case of lower clamping pressure ( 0.5 and $0.75 \mathrm{MPa})$, little increase in gas pressure further separated GDL and BPP locally. As there was already low contact pressure at the interface, the local separation led to an increase in the area specific ICR exponentially as investigated by P. Zhou et al. [49]. However, in the case of higher clamping pressure (1.25 and 1.5 MPa), relatively more gas pressure was required to separate out GDL and BPP. Therefore, slow increase in ICR was initially seen with the increase in gas pressure. The exponential increase in ICR after a threshold value (e.g. 6 bar in case of $1.5 \mathrm{MPa}$ ) was observed because of low average contact pressure at the interface. The maximum limit of the operating pressure for the URFC in the electrolyser mode of operation was estimated from the plot assuming the maximum allowed contact pressure to be $150 \mathrm{~m} \Omega \mathrm{cm}^{2}$ and observed that the maximum operating pressure varies linearly with the clamping pressure as given in the inset of Fig. 6.

\subsection{Polarization behavior}

The polarization behavior of the URFC in the electrolyser mode was studied at $65^{\circ} \mathrm{C}$ with a flow rate of water maintained approximately at $10 \mathrm{~mL} / \mathrm{min}$ at constant voltage mode ( $\mathrm{CV}$ mode). The 
settling time for current against each voltage set was $90 \mathrm{~s}$. The simulated polarization curve obtained from CFD modelling was validated with experimental results as shown in Fig. 7. It is observed that simulation results were in the good agreement with the experimental results. The effect of ICR was further studied on performances of the URFC. The variations in the polarization behavior for different clamping pressure is shown in Fig. 8a, keeping the operating pressure constant at 4 bar. Similarly, the variation in the polarization behavior of the URFC for different operating pressures keeping the clamping pressure constant at $1 \mathrm{MPa}$ are presented in Fig. 8b. The effect of an increase in gas pressure was seen in terms of increasing the cell resistance thereby reducing the performance.

\section{Conclusions}

In the present study, the performance of a URFC in electrolyser mode is modelled and also experimentally validated. The effect of the operating gas pressure arising from the variation in the contact pressure between GDL and BPP is studied. It is observed that the contact pressure decreases almost linearly with the increase in the operating gas pressure. Such trend is observed for all clamping pressures. Distribution of area specific ICR is observed to be relatively higher at the central portion of the electrode and lower at the peripheral portion of GDL. However, the exponential relation between ICR and contact pressure makes relatively larger clamping pressure to hold more gas pressure (as observed by C. Turan et al. [50]). To restrict the area specific resistance below $150 \mathrm{~m} \Omega \mathrm{cm}^{2}$ the operating pressure should be maintained below 5.9 bar at clamping pressure of 1.5 MPa. It should be noted that excessive clamping could bring ICR little lower, however, it will severely affect the cell components like GDL and membrane. It will also increase the mass transfer losses. The further incorporation of ICR in CFD for simulating the performance of URFC in electrolyser leads to an important conclusion of its impact on how 
drastically the performance could vary. Operating gas pressure and clamping pressure have been correlated with each other in the study with the help of modelling and it is observed that the maximum operating pressure of the URFC varies linearly with the clamping pressure. 


\section{References:}

[1] Winsche WE, Hoffman KC, Salzano FJ. Hydrogen: Its Future Role in the Nation's Energy Economy. Science (80- ) 1973;180:1325-32.

[2] Renn O. Social assemssment of waste energy utilization scenarios. Energy 2003;28:134557.

[3] Bergmeier M. The history of waste energy recovery in Germany since 1920. Energy 2003;28:1359-74.

[4] Sciubba E. Extended exergy accounding applied to energy recovery from waste: The concept of total recycling. Energy 2003;28:1315-34.

[5] Boukelia TE, Mecibah MS, Kumar BN, Reddy KS. Investigation of solar parabolic trough power plants with and without integrated TES (thermal energy storage) and FBS (fuel backup system) using thermic oil and solar salt. Energy 2015;88:292-303. doi:10.1016/j.energy.2015.05.038.

[6] Buttler A, Dinkel F, Franz S, Spliethoff H. Variability of wind and solar power - An assessment of the current situation in the European Union based on the year 2014. Energy 2016;106:147-61. doi:10.1016/j.energy.2016.03.041.

[7] Cavalcanti EJC, Motta HP. Exergoeconomic analysis of a solar-powered/fuel assisted Rankine cycle for power generation. Energy 2015;88:555-62. doi:10.1016/j.energy.2015.05.081.

[8] Killinger S, Mainzer K, McKenna R, Kreifels N, Fichtner W. A regional optimisation of renewable energy supply from wind and photovoltaics with respect to three key energypolitical objectives. Energy 2015;84:563-74. doi:10.1016/j.energy.2015.03.050.

[9] Sunderland KM, Narayana M, Putrus G, Conlon MF, McDonald S. The cost of energy associated with micro wind generation: International case studies of rural and urban 
installations. Energy 2016;109:818-29. doi:10.1016/j.energy.2016.05.045.

[10] ABAUND H, STEEB H. THE GERMAN-SAUDI HYSOLAR PROGRAM. Int J Hydrogen Energy 1998;23:445-9.

[11] Szyszka A. Ten years of solar hydrogen demonstration project at Neunburg vorm Wald, Germany. Int J Hydrogen Energy 1998;23:849-60. doi:10.1016/S0360-3199(97)00172-9.

[12] Szyszka A. Neumburg Vorm Wald-Test centre for solar hydrogen technology. Internaltional J Hydrog Energy 1994;19:823-41.

[13] Ghosh PC, Emonts B, Janßen H, Mergel J, Stolten D. Ten years of operational experience with a hydrogen-based renewable energy supply system. Sol Energy 2003;75:469-78. doi:10.1016/j.solener.2003.09.006.

[14] Bonnet C, Didierjean S, Guillet N, Besse S, Colinart T, Carré P. Design of an $80 \mathrm{kWe}$ PEM fuel cell system: Scale up effect investigation. J Power Sources 2008;182:441-8. doi:10.1016/j.jpowsour.2007.12.100.

[15] Gencoglu MT, Ural Z. Design of a PEM fuel cell system for residential application. Int J Hydrogen Energy 2009;34:5242-8. doi:10.1016/j.ijhydene.2008.09.038.

[16] Liu J, Luo W, Yang X, Wu L. Robust Model-Based Fault Diagnosis for PEM Fuel Cell Air-Feed System. IEEE Trans Ind Electron 2016;63:3261-70.

[17] Liu J, Laghrouche S, Wack M. Observer-based higher order sliding mode control of power factor in three-phase AC/DC converter for hybrid electric vehicle applications. Int J Control 2014;87:1117-30. doi:10.1080/00207179.2013.868609.

[18] Raj AS, Ghosh PC. Standalone PV-diesel system vs. PV-H H $_{2}$ system: An economic analysis. Energy 2012;42:270-80.

[19] Verma A, Basu S. Feasibility study of a simple unitized regenerative fuel cell. J Power 
Sources 2004;135:62-5. doi:10.1016/j.jpowsour.2004.03.077.

[20] Chávez-Ramírez AU, Cruz JC, Espinosa-Lumbreras R, Ledesma-García J, Durón-Torres SM, Arriaga LG. Design and set up of a hybrid power system (PV-WT-URFC) for a stand-alone application in Mexico. Int J Hydrogen Energy 2013;38:12623-33. doi:http://dx.doi.org/10.1016/j.ijhydene.2012.11.019.

[21] Ganguly A, Misra D, Ghosh S. Modeling and analysis of solar photovoltaic-electrolyzerfuel cell hybrid power system integrated with a floriculture greenhouse. Energy Build 2010;42:2036-43. doi:10.1016/j.enbuild.2010.06.012.

[22] Wang X, Shang J, Luo Z, Tang L, Zhang X, Li J. Reviews of power systems and environmental energy conversion for unmanned underwater vehicles. Renew Sustain Energy Rev 2012;16:1958-70. doi:10.1016/j.rser.2011.12.016.

[23] Roca-Ayats M, Garcia G, Galante JL, Peria MA, Martinez-Huerta MV. Eletrocatalytic stability of Ti based-supported $\mathrm{Pt}_{3} \mathrm{Ir}$ nanoparticles for unitized regenerative fuel cells. Int $\mathrm{J}$ Hydrogen Energy 2014;39:5477-84.

[24] Nakano A, Maeda T, Ito H, Masuda M, Kawakami Y, Tange M, et al. Study on absorption/desorption characteristics of a metal hydride tank for boil-off gas from liquid hydrogen. Int J Hydrogen Energy 2012;37:5056-62. doi:10.1016/j.ijhydene.2011.12.021.

[25] Zhou Y, Lin G, Shih a. J, Hu SJ. A micro-scale model for predicting contact resistance between bipolar plate and gas diffusion layer in PEM fuel cells. J Power Sources 2007;163:777-83. doi:10.1016/j.jpowsour.2006.09.019.

[26] Chang WR, Hwang JJ, Weng FB, Chan SH. Effect of clamping pressure on the performance of a PEM fuel cell. J Power Sources 2007;166:149-54. doi:10.1016/j.jpowsour.2007.01.015. 
[27] Lai X, Liu D, Peng L, Ni J. A mechanical-electrical finite element method model for predicting contact resistance between bipolar plate and gas diffusion layer in PEM fuel cells. J Power Sources 2008;182:153-9. doi:10.1016/j.jpowsour.2008.03.069.

[28] Singdeo D, Dey T, Ghosh PC. Contact resistance between bipolar plate and gas diffusion layer in high temperature polymer electrolyte fuel cells. Int J Hydrogen Energy 2014;39:987-95. doi:10.1016/j.ijhydene.2013.10.147.

[29] Zhou P, Lin P, Wu CW, Li Z. Effect of nonuniformity of the contact pressure distribution on the electrical contact resistance in proton exchange membrane fuel cells. Int $\mathbf{J}$ Hydrogen Energy 2011;36:6039-44. doi:10.1016/j.ijhydene.2011.01.080.

[30] Khurana S, Hall DM, Schatz RS, Lvov SN. Effect of Clamping Pressure and Temperature on the Performance of a $\mathrm{CuCl}(\mathrm{aq}) / \mathrm{HCl}(\mathrm{aq})$ Electrolyzer. ECS Electrochem Lett 2015;4:F21-3. doi:10.1149/2.0011504eel.

[31] Montanini R, Squadrito G, Giacoppo G. Measurement of the clamping pressure distribution in polymer electrolyte fuel cells using piezoresistive sensor arrays and digital image correlation techniques. J Power Sources 2011;196:8484-93. doi:10.1016/j.jpowsour.2011.06.017.

[32] Kraytsberg A, Auinat M, Ein-Eli Y. Reduced contact resistance of PEM fuel cell's bipolar plates via surface texturing. J Power Sources 2007;164:697-703.

[33] Lin MT, Wan $\mathrm{CH}, \mathrm{Wu}$ W. Comparison of corrosion behaviors between SS304 and Ti substrate coated with $(\mathrm{Ti}, \mathrm{Zr}) \mathrm{N}$ thin films as Metal bipolar plate for unitized regenerative fuel cell. Thin Solid Films 2013;544:162-9. doi:10.1016/j.tsf.2013.03.130.

[34] Zhang H, Hou M, Lin G, Han Z, Fu Y, Sun S, et al. Performance of Ti-Ag-deposited titanium bipolar plates in simulated unitized regenerative fuel cell (URFC) environment. 
Int J Hydrogen Energy 2011;36:5695-701. doi:10.1016/j.ijhydene.2011.01.154.

[35] Zhanga M, Hu L, Lin G, Shao Z. Honeycomb-like nanocomposite Ti-Ag-N films prepared by pulsed bias arc ion plating on titanium as bipolar plates for unitized regenerative fuel cells. J Power Sources 2012;198:196-202. doi:10.1016/j.jpowsour.2011.10.022.

[36] Oyarce A, Holmström N, Bodén A, Lagergren C, Lindbergh G. Operating conditions affecting the contact resistance of bi-polar plates in proton exchange membrane fuel cells. J Power Sources 2013;231:246-55. doi:10.1016/j.jpowsour.2012.12.100.

[37] Bates A, Mukherjee S, Hwang S, Lee SC, Kwon O, Choi GH, et al. Simulation and experimental analysis of the clamping pressure distribution in a PEM fuel cell stack. Int J Hydrogen Energy 2013;38:6481-93. doi:10.1016/j.ijhydene.2013.03.049.

[38] Dey T, Singdeo D, Bose M, Basu RN, Ghosh PC. Study of contact resistance at the electrode-interconnect interfaces in planar type Solid Oxide Fuel Cells. J Power Sources 2013;233:290-8. doi:10.1016/j.jpowsour.2013.01.111.

[39] Lee WK, Ho CH, Van Zee JW, Murthy M. Effects of compression and gas diffusion layers on the performance of a PEM fuel cell. J Power Sources 1999;84:45-51. doi:10.1016/S0378-7753(99)00298-0.

[40] Bograchev D, Gueguen M, Grandidier J-C, Martemianov S. Stress and plastic deformation of MEA in fuel cells. J Power Sources 2008;180:393-401. doi:10.1016/j.jpowsour.2008.02.048.

[41] Selamet OF, Ergoktas MS. Effects of bolt torque and contact resistance on the performance of the polymer electrolyte membrane electrolyzers. J Power Sources 2015;281:103-13. doi:10.1016/j.jpowsour.2015.01.162.

[42] Siracusano S, Di Blasi a., Baglio V, Brunaccini G, Briguglio N, Stassi a., et al. 
Optimization of components and assembling in a PEM electrolyzer stack. Int J Hydrogen Energy 2011;36:3333-9. doi:10.1016/j.ijhydene.2010.12.044.

[43] Lu JL, Fang QH, Li SL, Jiang SP. A novel phosphotungstic acid impregnated mesoNafion multilayer membrane for proton exchange membrane fuel cells. J Memb Sci 2013;427:101-7. doi:10.1016/j.memsci.2012.09.041.

[44] Annapurna B, Meenakshi S, Bhat SD, Seshadri S. Microbial extracellular polysaccharidebased membrane in polymer electrolyte fuel cells. Chem Eng J 2013;231:373-9. doi:10.1016/j.cej.2013.07.042.

[45] Thanasilp S, Hunsom M. Effect of MEA fabrication techniques on the cell performance of $\mathrm{Pt}-\mathrm{Pd} / \mathrm{C}$ electrocatalyst for oxygen reduction in PEM fuel cell. Fuel 2010;89:3847-52. doi:10.1016/j.fuel.2010.07.008.

[46] Bard AJ, Faulkner LR. ELECTROCHEMICAL METHODS Fundamentals and applications. 2001. doi:10.1038/nprot.2009.120.Multi-stage.

[47] Um S, Wang C, Chen KS. Computational Fluid Dynamics Modeling of Proton Exchange Membrane Fuel Cells. J Electrochem Soc 2000;147:4485-93.

[48] Wang L, Northwood DO, Nie X, Housden J, Spain E, Leyland a., et al. Corrosion properties and contact resistance of $\mathrm{TiN}$, TiAlN and $\mathrm{CrN}$ coatings in simulated proton exchange membrane fuel cell environments. J Power Sources 2010;195:3814-21. doi:10.1016/j.jpowsour.2009.12.127.

[49] Zhou P, Wu CW, Ma GJ. Influence of clamping force on the performance of PEMFCs. J Power Sources 2007;163:874-81. doi:10.1016/j.jpowsour.2006.09.068.

[50] Turan C, Cora ON, Koc M. Contact resistance characteristics of coated metallic bipolar plates for PEM fuel cells - Investigations on the effect of manufacturing. Int J Hydrogen 
Energy 2012;37:18187-204. doi:10.1016/j.ijhydene.2012.09.042.

[51] AK Steel Corporation. Retrieved October 1, 2015, from http://www.aksteel.com/. AK Steel 2007:2. doi:10.1016/B978-0-444-89875-3.50030-2.

[52] FuelCellsEtc. Retrieved September 23, 2015, from http://fuelcellsetc.com/store/Layers/Carbon-Paper/toray-paper and http://fuelcellsetc.com/store/DS/Toray-Paper-TGP-H-Datasheet.pdf.

[53] FuelCellsEtc. Retrieved September 23, 2015, from http://fuelcellsetc.com/store/N212 2008:6 


\section{Acknowledgement}

This research is based upon work supported by the Solar Energy Research Institute for India and the U.S. (SERIIUS) funded jointly by the U.S. Department of Energy subcontract DE AC3608G028308 (Office of Science, Office of Basic Energy Sciences, and Energy Efficiency and

Renewable Energy, Solar Energy Technology Program, with support from the Office of International Affairs) and the Government of India subcontract IUSSTF/JCERDCSERIIUS/2012 dated 22nd Nov. 2012. 


\section{Nomenclature:}

\begin{tabular}{|c|c|}
\hline $\mathrm{A}_{\text {electrode }}$ & Active area of the cell, $\mathrm{m}^{2}$ \\
\hline$\alpha$ & Transfer coefficient \\
\hline$[C]$ & Local species concentration, $\mathrm{kmol} \mathrm{m}^{-3}$ \\
\hline$[C]_{\text {ref }}$ & Reference concentration, $\mathrm{kmol} \mathrm{m}^{-3}$ \\
\hline$C P$ & Average contact pressure, bar \\
\hline$\Delta \mathrm{C}_{\mathrm{p}}$ & Specific heat of the reaction, $\mathrm{J} \mathrm{mol}^{-1} \mathrm{~K}^{-1}$ \\
\hline$E$ & Operating potential of electrolyser, V \\
\hline$E_{\text {rev }}^{0}$ & Reversible potential of electrolyser at STP conditions, V \\
\hline$E_{r e v}^{T}$ & Reversible potential of electrolyser at temperature $\mathrm{T}, \mathrm{V}$ \\
\hline$E^{N}=E^{P, T}$ & Nernst or reversible potential at different operating pressure and temperature, $\mathrm{V}$ \\
\hline$F$ & Faraday constant $\left(96485 \mathrm{C} \mathrm{mol}^{-1}\right)$ \\
\hline$\Delta G$ & Gibbs free energy (electrical input for water splitting), $\mathrm{kJ} \mathrm{kg}^{-1}$ \\
\hline$\Delta H$ & Change in enthalpy, $\mathrm{kJ} \mathrm{kg}^{-1}$ \\
\hline$J_{a n}$ & Volumetric current density for anode, $\mathrm{A} \mathrm{m}^{-3}$ \\
\hline$J_{\text {cat }}$ & Volumetric current density for cathode, $\mathrm{A} \mathrm{m}^{-3}$ \\
\hline$j_{a n}^{r e f}$ & Reference exchange current density per active surface area for anode, $\mathrm{A} \mathrm{m}^{-2}$ \\
\hline$j_{\text {cat }}^{r e f}$ & Reference exchange current density per active surface area for cathode, $\mathrm{A} \mathrm{m}^{-2}$ \\
\hline$J_{\text {avg }}$ & Average current density supplied for water electrolysis, $\mathrm{A} \mathrm{cm}^{-2}$ \\
\hline$\zeta_{a n}$ & Specific active surface area of anode catalyst, $\mathrm{m}^{-1}$ \\
\hline$\zeta_{\text {cat }}$ & Specific active surface area of cathode catalyst, $\mathrm{m}^{-1}$ \\
\hline $\mathrm{m}_{\mathrm{H}_{2}}^{\cdot}$ & Molar flow rate of hydrogen produced, $\mathrm{mol} \mathrm{s}^{-1}$ \\
\hline$M_{w, H_{2}}$ & Molecular weight of hydrogen, $\mathrm{kg} \mathrm{mol}^{-1}$ \\
\hline
\end{tabular}




\begin{tabular}{|c|c|}
\hline$M_{w, O_{2}}$ & Molecular weight of oxygen, $\mathrm{kg} \mathrm{mol}^{-1}$ \\
\hline$M_{w, H_{2} O}$ & Molecular weight of water, $\mathrm{kg} \mathrm{mol}^{-1}$ \\
\hline MEA & Membrane electrode assembly \\
\hline $\mathrm{n}$ & Number of electrons per mole, $\mathrm{mol}^{-1}$ \\
\hline$\eta_{a n}$ & Activation overpotential of oxygen electrode (anode), $\mathrm{V}$ \\
\hline$\eta_{\text {cat }}$ & Activation overpotential of hydrogen electrode (cathode), V \\
\hline $\mathrm{OCV}$ & Open circuit voltage, $\mathrm{V}$ \\
\hline$P_{H_{2}}$ & Partial pressure of hydrogen $=$ operating pressure of hydrogen, atm \\
\hline$P_{O_{2}}$ & Partial pressure of oxygen $=$ operating pressure of oxygen, atm \\
\hline$P_{\mathrm{H}_{2} \mathrm{O}}$ & Activity of water \\
\hline$R$ & Universal gas constant $\left(8.314 \mathrm{~J} \mathrm{~mol}^{-1} \mathrm{~K}^{-1}\right)$ \\
\hline$R_{B P P}$ & Bulk resistance of BPP, $\Omega$ \\
\hline$R_{G D L}$ & Bulk resistance of GDL, $\Omega$ \\
\hline$R_{\text {connections }}$ & Bulk resistance of electrical connections, $\Omega$ \\
\hline$R_{e_{-} t o t}$ & Total electronic resistance, $\Omega$ \\
\hline$R_{\text {tot }}$ & Total resistance in the cell, $\Omega$ \\
\hline$R_{\text {act }}$ & Resistance due to activation, $\Omega$ \\
\hline$R_{\text {ohmic }}$ & Ionic resistance, $\Omega$ \\
\hline$R_{I C R}$ & Resistance due to ICR, $\Omega \mathrm{m}^{2}$ \\
\hline$\Delta S$ & Change in entropy (thermal input for water splitting), $\mathrm{kJ} \mathrm{kg}^{-1} \mathrm{~K}^{-1}$ \\
\hline$\Delta S^{0}$ & Entropy of the reaction at STP condition, $\mathrm{J} \mathrm{mol}^{-1} \mathrm{~K}^{-1}$ \\
\hline$S_{H_{2}}$ & Source term for hydrogen, $\mathrm{kg} \mathrm{m}^{-3} \mathrm{~s}^{-1}$ \\
\hline$S_{O_{2}}$ & Source term for oxygen, $\mathrm{kg} \mathrm{m}^{-3} \mathrm{~s}^{-1}$ \\
\hline
\end{tabular}




$\begin{array}{ll}S_{H_{2}} & \text { Source term for water, } \mathrm{kg} \mathrm{m}^{-3} \mathrm{~s}^{-1} \\ T & \text { Absolute temperature of electrolysis, } \mathrm{K} \\ y & \text { Concentration dependence }\end{array}$

\section{Abbreviations}

BPP Bipolar plate

CFD Computational fluid dynamics

$\mathrm{CP} \quad$ Average contact pressure

DAQ Data acquisition system

FC Fuel cell mode

GDL Gas diffusion layer

ICR Interfacial contact resistance

IPA Iso-propyl alcohol

MEA Membrane electrode assembly

PEM Polymer electrolyte membrane/ proton exchange membrane

PTFE Polytetrafluroethylene

RH Relative humidity

Ti Titanium

TiN Titanium nitride

URFC Unitized regenerative fuel cell 


\section{List of Figures}

Fig. 1. Experimental setup (left) with device schematically illustrated (right)

Fig. 2. Various components of the cell with MEA and actual cell fabricated (inset)

Fig. 3. ICR for carbon paper and SS316 coated with TiN

Fig. 4. Detailed analysis of contact pressure and its distribution over electrode (a) simulated at 1 MPa clamping pressure (b) experimental 2D contour plots of stress (c) distribution of stress over electrode area, (d) variation of average contact pressure

Fig. 5. Variation of contact pressure with gas pressure at different clamping pressures

Fig. 6. Variation of ICR over operating gas pressure at different clamping pressure; (inset) gas pressure at various clamping pressure for threshold ICR of $150 \mathrm{~m} \Omega \mathrm{cm}^{2}$

Fig. 7. Comparison of simulated and experimental IV curve for the electrolyser

Fig. 8. Comparison of characteristic curves for different (a) clamping pressures at 4 bar of operating pressure (b) operating pressure with $1 \mathrm{MPa}$ of clamping pressure

\section{List of table}

Table 1. Material properties of different components of URFC 


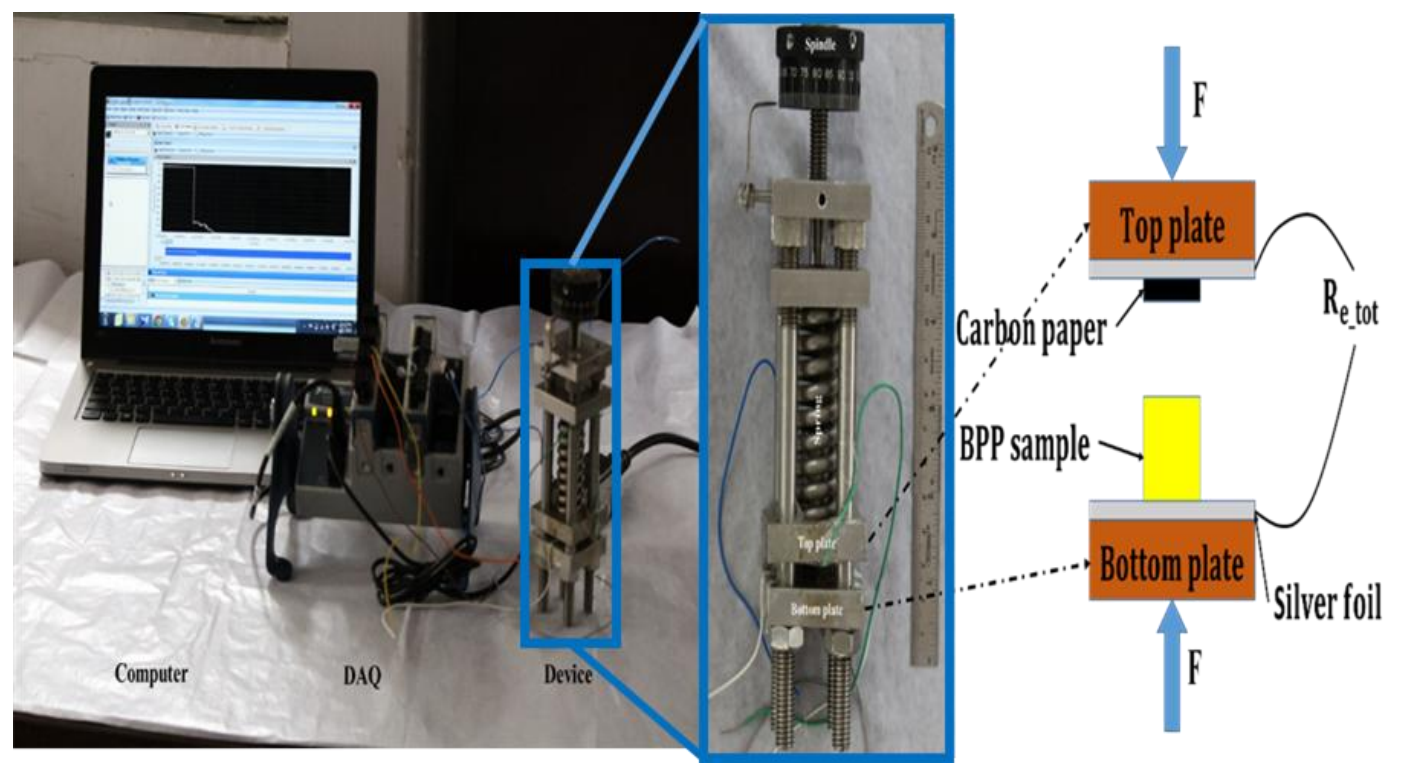

Fig. 1.

Figure 


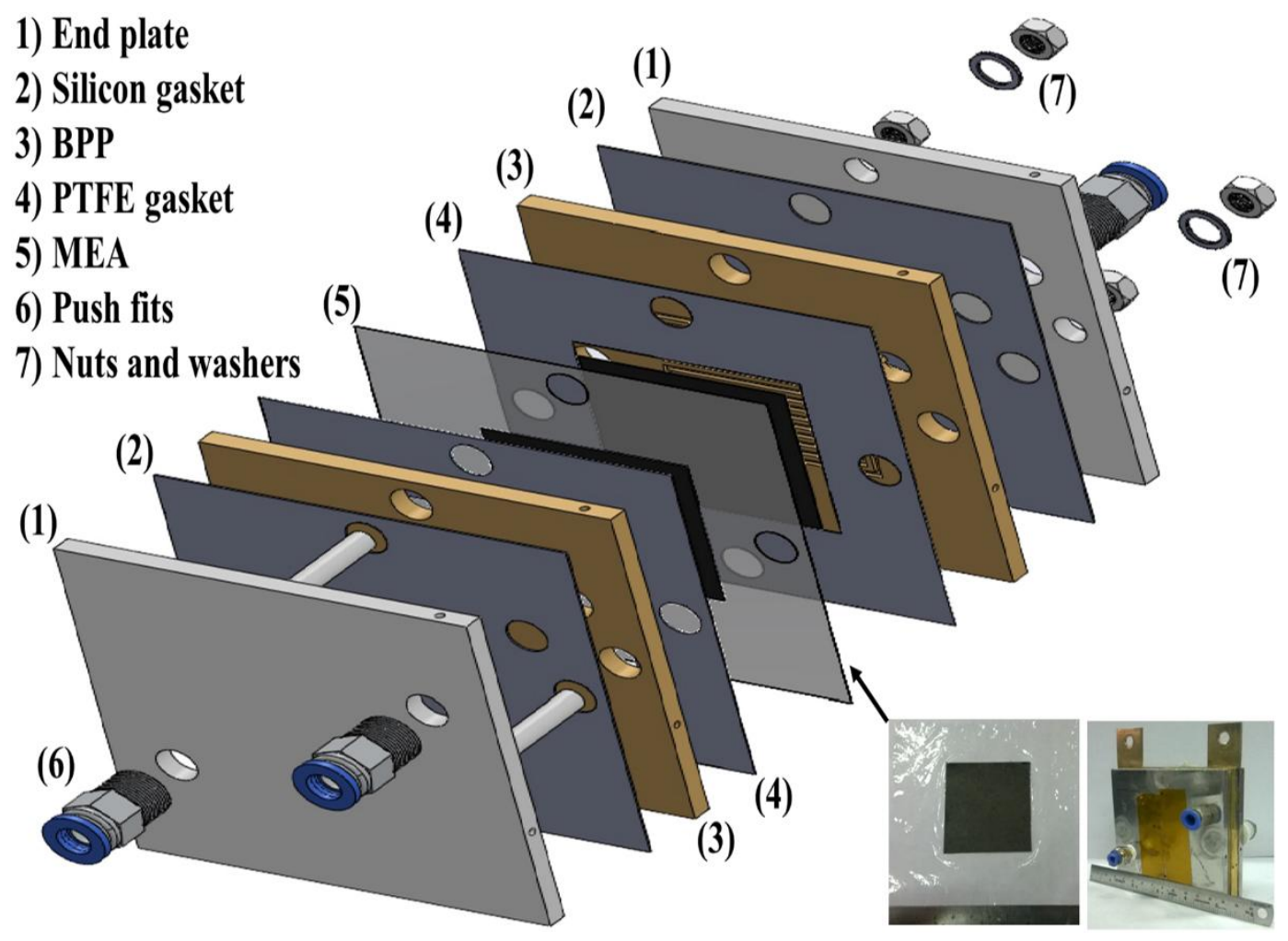

Fig. 2. 


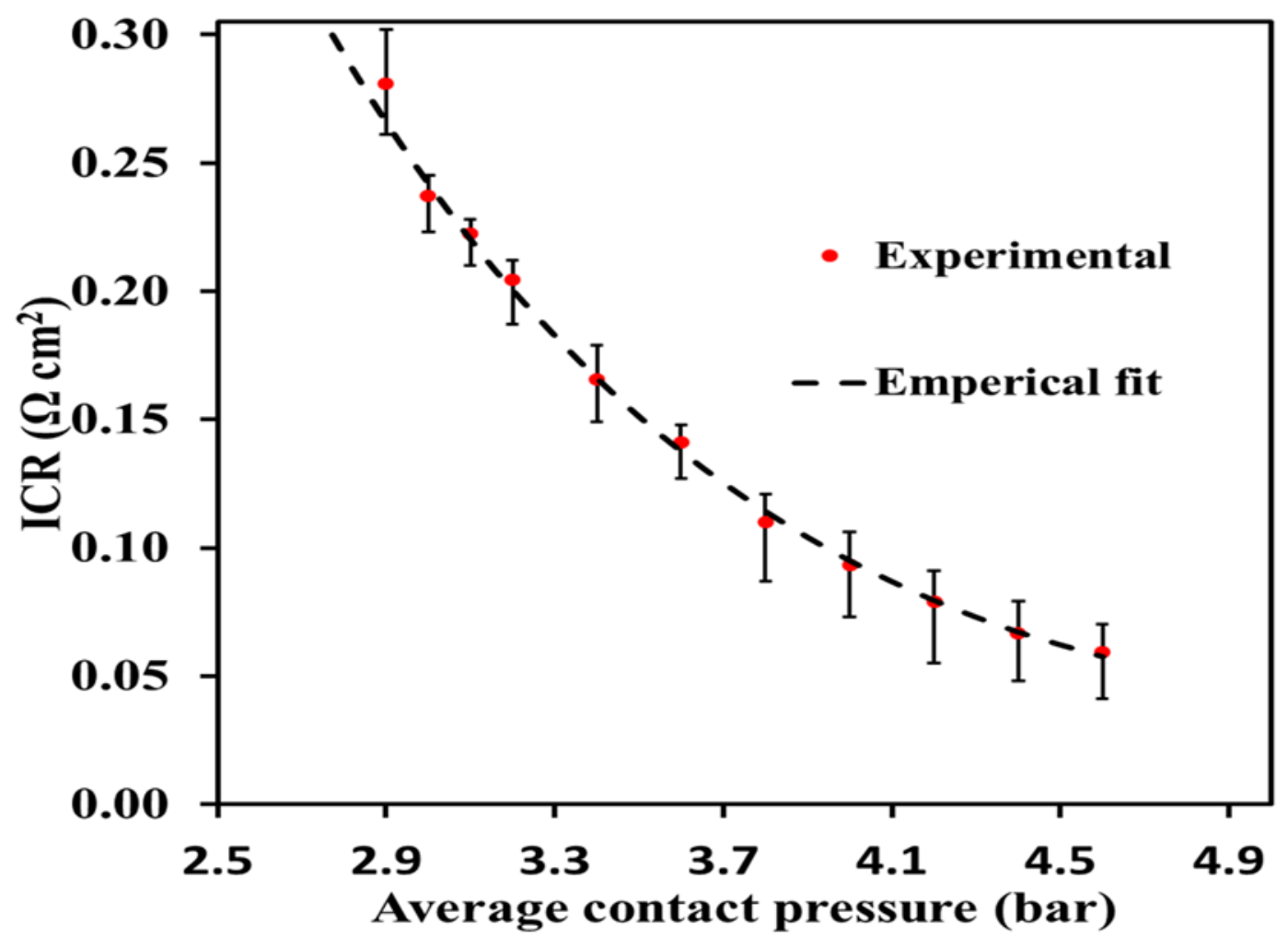

Fig. 3. 

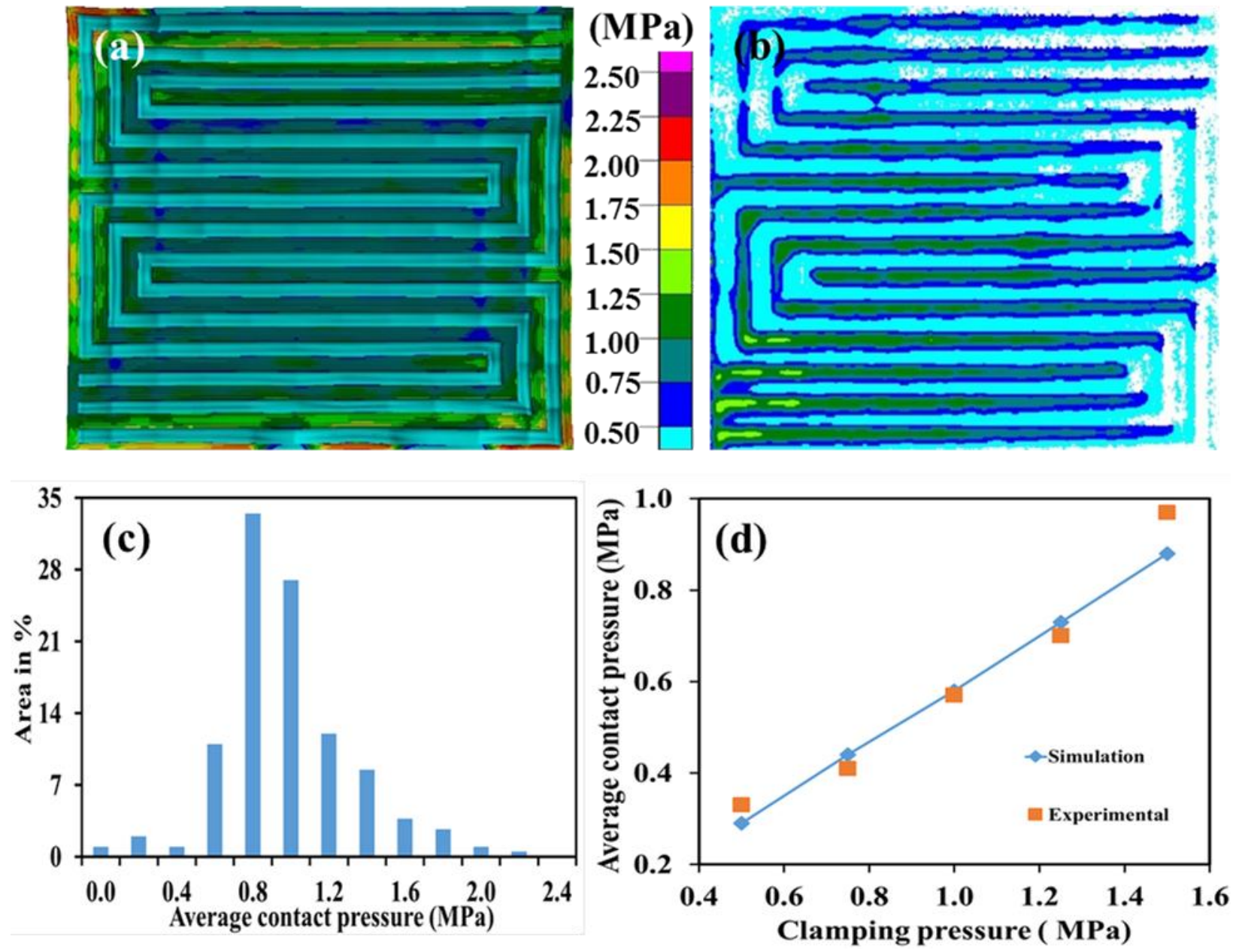

Fig. 4. 


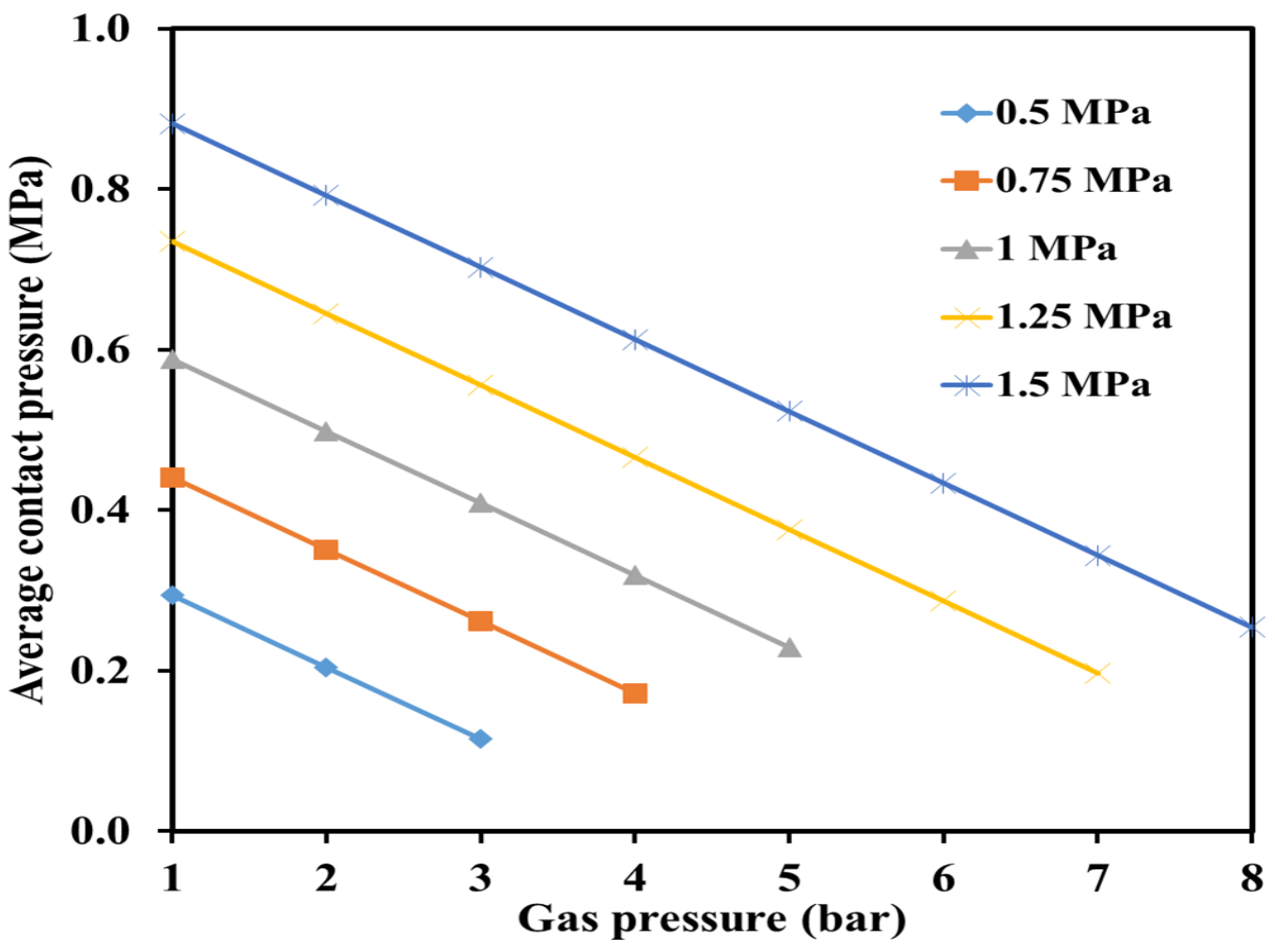

Fig. 5. 


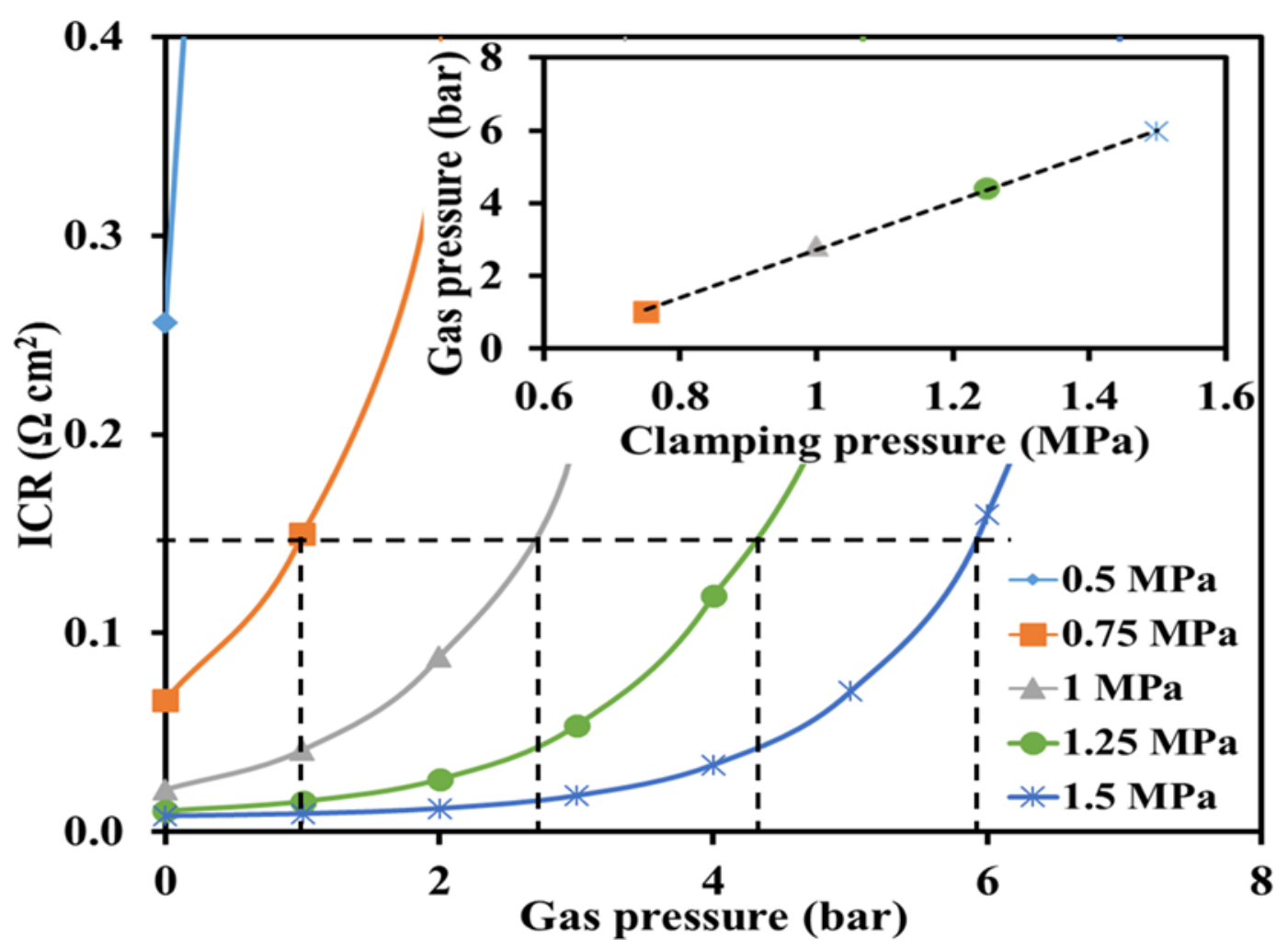

Fig. 6. 


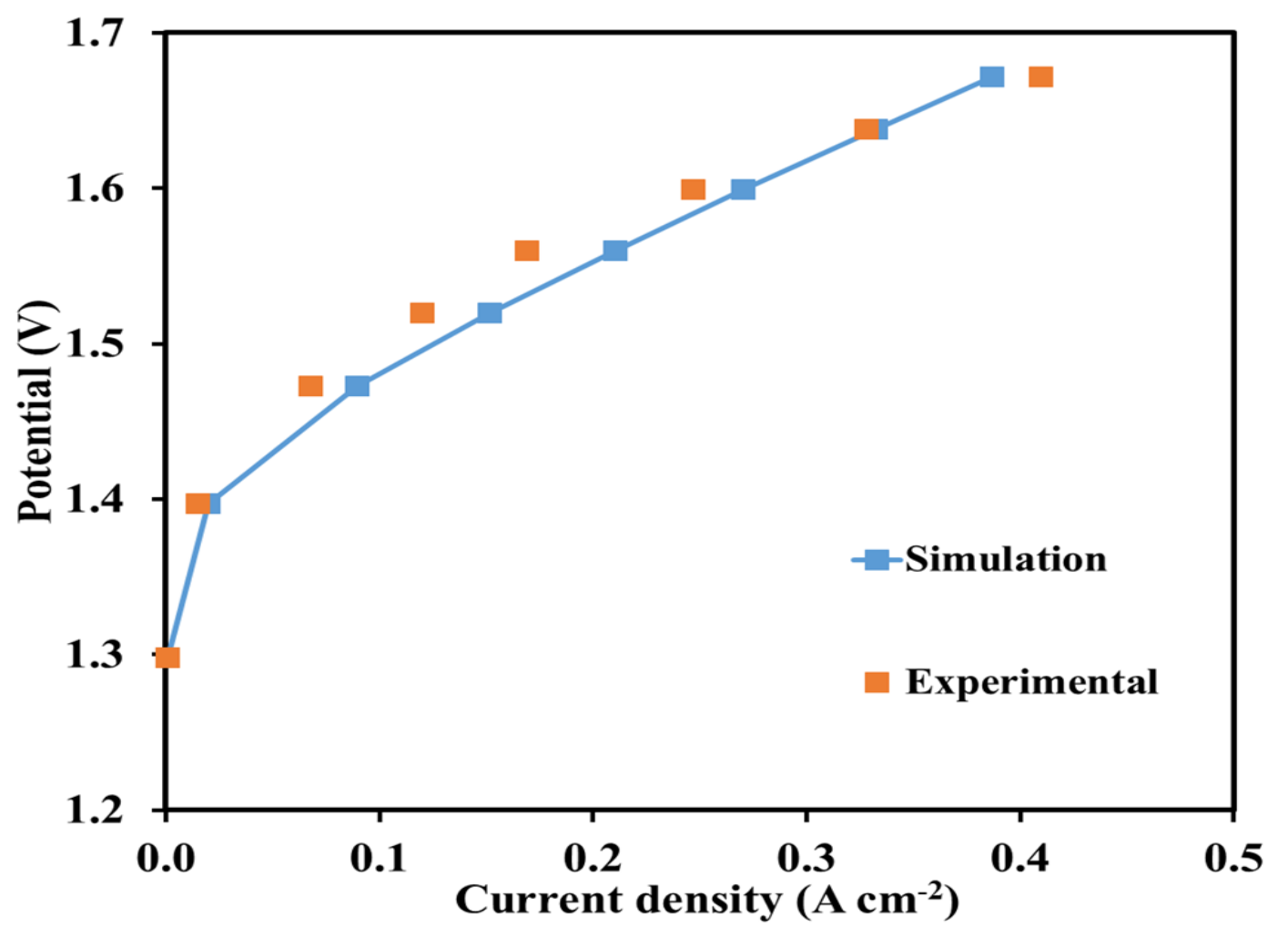

Fig. 7. 

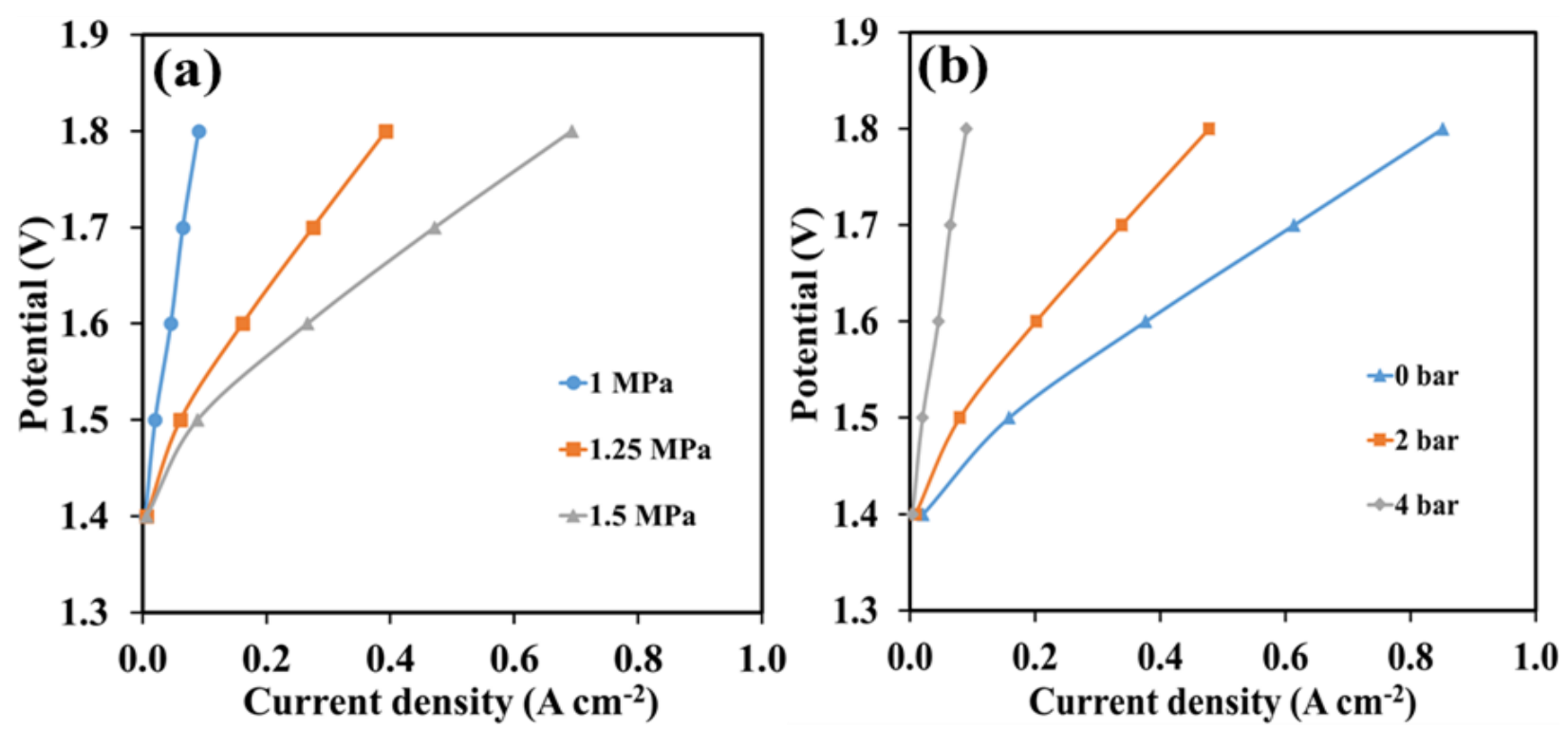

Fig. 8. 
Table 1

\begin{tabular}{llccc}
\hline Component & Material & Young's modulus & Density & Poisson's ratio \\
& & $(\mathrm{GPa})$ & $\left(\mathrm{kgm}^{-3}\right)$ & \\
\hline End plate [51] & SS 316 & 193 & 8000 & 0.3 \\
Silicon Gasket & Silicon & 0.017 & 1500 & 0.47 \\
BPP [51] & SS 316 coated & 193 & 8000 & 0.3 \\
& with TiN & & & 0.46 \\
PTFE gasket & PTFE & 79 & 2200 & 0.3 \\
GDL [52] & Toray paper & 10 & 450 & \\
& (TGP-H-120) & & & 0.25 \\
Membrane [53] & NR-212 & & 2000 & \\
\hline
\end{tabular}

